Marquette University

e-Publications@Marquette

Biomedical Sciences Faculty Research and

Publications

Biomedical Sciences, Department of

6-1-2014

Inhibition of Food Intake by PACAP in the Hypothalamic Ventromedial Nuclei is Mediated by NMDA Receptors

Jon M. Resch

Marquette University, jon.resch@marquette.edu

Brian Maunze

Marquette University, brian.maunze@marquette.edu

Kailynn A. Phillips

Marquette University, kailynn.phillips@marquette.edu

Sujean Choi

Marquette University, sujean.choi@marquette.edu

Accepted version. Physiology \& Behavior, Vol.133, No. 22 (June 2014): 230-235. DOI. (C) 2014 Elsevier. Used with permission. 


\title{
Inhibition of Food Intake by PACAP in the Hypothalamic Ventromedial Nuclei Is Mediated by NMDA Receptors
}

\author{
Jon M. Resch \\ Biomedical Sciences, Marquette University \\ Milwaukee, WI \\ Brian Maunze \\ Biomedical Sciences, Marquette University \\ Milwaukee, WI \\ Kailynn A. Phillips \\ Biomedical Sciences, Marquette University \\ Milwaukee, WI \\ SuJean Choi \\ Biomedical Sciences, Marquette University \\ Milwaukee, WI
}

\begin{abstract}
:
Central injections of Pituitary adenylate cyclase-activating polypeptide (PACAP) into the ventromedial nuclei (VMN) of the hypothalamus produce hypophagia that is dependent upon the PAC1 receptor, however, the signaling

Physiology \& Behavior, Vol. 133, No. 22 (June 2014): pg. 230-235. DOI. This article is (C Elsevier and permission has been granted for this version to appear in e-Publications@Marquette. Elsevier does not grant permission for this article to be further copied/distributed or hosted elsewhere without the express permission from Elsevier.
\end{abstract}


NOT THE PUBLISHED VERSION; this is the author's final, peer-reviewed manuscript. The published version may be accessed by following the link in the citation at the bottom of the page.

downstream of this receptor in the VMN is unknown. Though PACAP signaling has many targets, this neuropeptide has been shown to influence glutamate signaling in several brain regions through mechanisms involving NMDA receptor potentiation via activation of the Src family of protein tyrosine kinases. With this in mind, we examined the Src-NMDA receptor signaling pathway as a target for PACAP signaling in the VMN that may mediate its effects on feeding behavior. Under nocturnal feeding conditions, NMDA receptor antagonism prior to PACAP administration into the VMN attenuated PACAP-mediated decreases in feeding suggesting glutamatergic signaling via NMDA receptors is necessary for PACAP-induced hypophagia. Furthermore, PACAP administration into the VMN resulted in increased tyrosine phosphorylation of the GluN2B subunit of the NMDA receptor, and inhibition of Src kinase activity also blocked the effects of PACAP administration into the VMN on feeding behavior. These results indicate that PACAP neurotransmission in the VMN likely augments glutamate signaling by potentiating NMDA receptors activity through tyrosine phosphorylation events mediated by the Src kinase family, and modulation of NMDA receptor activity by PACAP in the hypothalamus may be a primary mechanism for its regulation of food intake.

Keywords: feeding, VMN, glutamate, Src kinase, PACAP.

\section{Introduction}

Hypothalamic glutamate neurotransmission is crucial to energy balance [1-6], in part, through the regulation of feeding behavior [79]. This is in contrast to classical views of hypothalamic signaling that have focused on the importance of neuropeptides for homeostatic regulation. However, recent investigations into mechanisms of neuropeptide function have indicated that modulation of the fastacting amino acid neurotransmitters, glutamate and GABA, may be a primary role for neuropeptide signaling [10]. For example, the neuropeptides orexin and neuropeptide Y (NPY) both potently increase feeding behavior through glutamate receptor-dependent signaling pathways in the lateral hypothalamus $[11,12]$ and that orexin causes enhancement of presynaptic glutamate release and postsynaptic NMDA receptor activity in the ventral tegmental area [13].

The hypothalamic ventromedial nuclei (VMN) are critical regulators of body weight and possess both high levels of glutamate and all glutamate receptor subtypes [4, 14-16]. Stimulation of these nuclei produces reductions in food intake and increased metabolic rate

Physiology \& Behavior, Vol. 133, No. 22 (June 2014): pg. 230-235. DOI. This article is @ Elsevier and permission has been granted for this version to appear in e-Publications@Marquette. Elsevier does not grant permission for this article to be further copied/distributed or hosted elsewhere without the express permission from Elsevier. 
[8, 17-20]. Likewise, microinjection of the pleiotropic neuropeptide pituitary adenylate cyclase-activating polypeptide (PACAP) into the VMN inhibits feeding behavior through activation of PAC1 receptors even after food deprivation [21, 22], however, the VMN neuronal signaling downstream of PAC1R leading to decreased food intake is currently unknown. However, previous demonstration of synergy between PACAP and glutamate [23-25] in other brain regions suggests that PACAP-PAC1R signaling in the VMN may lead to augmented glutamate neurotransmission.

Co-localization of PACAP and glutamate immunoreactivity in retinal ganglion cells, as well as in nerve terminals located in the suprachiasmatic nuclei (SCN) support a mechanism of co-release at synapses of the retinohypothalamic tract $[23,26,27]$. Functionally, PACAP application to SCN slices produces dose-dependent phase shifts in circadian rhythms through modulation of NMDA receptor activity [24]. In another brain region, PACAP enhances NMDA receptor activity in the hippocampus, reportedly by two separate mechanisms involving Src tyrosine kinase signaling. The first of which involves CAMP/PKAdependent activation of Fyn, a member of the Src tyrosine kinase family, leading to phosphorylation of multiple tyrosine residues on the GluN2B subunit of the NMDA receptor [28], while the second was shown to occur via PAC1R activation of a phospholipase $C$ pathway leading to Src tyrosine kinase activation and augmented hippocampal NMDA receptor function [25]. Both PACAP-mediated signaling pathways reported in the hippocampus suggest that modulation of NMDA receptors can occur through Src family kinase activity, which has been implicated in the regulation of feeding behavior by lateral hypothalamic neurons [29].

In order to determine whether modulation of glutamatergic NMDA receptor signaling underlies the regulation of feeding behavior by PACAP in the hypothalamus we measured nocturnal food intake following pharmacological inhibition of NMDA receptor function within the VMN prior to PACAP injection. Moreover, we analyzed tyrosine phosphorylation of NMDA receptors following PACAP administration and examined whether activity of Src family kinases is important for PACAP-mediated alterations of feeding behavior in the VMN. Our results suggest that NMDA receptor activity is necessary for PACAP-

Physiology \& Behavior, Vol. 133, No. 22 (June 2014): pg. 230-235. DOI. This article is (C) Elsevier and permission has been granted for this version to appear in e-Publications@Marquette. Elsevier does not grant permission for this article to be further copied/distributed or hosted elsewhere without the express permission from Elsevier. 
induced hypophagia in the VMN, and PACAP may act through stimulation of Src kinases to augment NMDA receptors function.

\section{Methods}

\section{Animals}

Male Sprague-Dawley rats (Harlan; Madison, WI) weighing 225$250 \mathrm{~g}$ were individually housed in a climate controlled room with a 12 hr light/dark cycle. Animals had free access to Harlan standard diet (8604 formulation) and water. Food consumption was measured with a BioDAQ Food Intake Monitor (Research Diets; New Brunswick, NJ) or calculated by pre-weighing food in each bin and subtracting the weight of non-ingested and spilled food at the end of each measurement period. All procedures using animals were approved by the Marquette University Institutional Animal Care and Use Committee.

\section{Surgery}

Animals were anesthetized with a ketamine/xylazine/acepromazine (77:1.5:1.5 mg/ml/kg; ip) cocktail and placed in a stereotaxic apparatus. Bilateral guide cannulae (26 gauge; Plastics One; Roanoke VA) were placed $3 \mathrm{~mm}$ dorsal to the target site in all animals, and secured to the surface of the skull with an acrylic resin. The stereotaxic coordinates for the VMN were anterior/posterior, $-2.5 \mathrm{~mm}$ from bregma; medial/lateral, $\pm 0.6 \mathrm{~mm}$ from midline; dorsal/ventral, $6.2 \mathrm{~mm}$ from surface of the skull based on The Rat Brain in Stereotaxic Coordinates, $6^{\text {th }}$ Edition [30]. Injectors extended $3 \mathrm{~mm}$ past the ventral tip of the cannulae reaching a VMN injection site of $\mathbf{- 9 . 2 \mathrm { mm }}$ ventral from the surface of the skull. The upper incisor bar was positioned $-3.3 \mathrm{~mm}$ below horizontal zero. A bilateral dummy stylet placed in the guide cannulae was used to maintain patency. All animals were given at least five days to recover after cannula installation before receiving drug or vehicle injections, during which time the animals were handled and dummy stylets were removed and replaced daily in order to acclimate the animals to the physical handling necessary during experiments. Correct cannulae placements were confirmed at the conclusion of each experiment by microscopic examination of Nissl stained sections and only those with correct placement were included in the studies.

Physiology \& Behavior, Vol. 133, No. 22 (June 2014): pg. 230-235. DOI. This article is @ Elsevier and permission has been granted for this version to appear in e-Publications@Marquette. Elsevier does not grant permission for this article to be further copied/distributed or hosted elsewhere without the express permission from Elsevier. 


\section{Feeding Behavior Experiments}

Animals were weighed daily and acclimated to the BioDAQ Food Intake Monitor for at least 7 days before the onset of the experiment. In all experiments, approximately 1 hour prior to lights off rats received bilateral microinjections of vehicle, D-(-)-2-amino-5phosphonopentanoic acid (AP5; $10 \mathrm{pmol}-1 \mathrm{nmol}$ in saline/0.25 $\mathrm{\mu l} /$ side; Tocris Bioscience), or 1-(1,1-Dimethylethyl)-1-(4methylphenyl)-1H-pyrazolo[3,4- $d$ ] pyrimidin-4-amine (PP1; Src kinase inhibitor; $1-100 \mathrm{pmol}$ in $10 \% \mathrm{DMSO} / 0.25 \mu \mathrm{l} /$ side; $1 \mathrm{nmol}$ in $25 \%$ DMSO/0.25 $\mu \mathrm{l} / \mathrm{side}$; Tocris Bioscience) over approximately two minutes in awake animals while gently restrained. When necessary, DMSO was used as a vehicle for water insoluble substances such as PP1, as it has been previously verified to be suitable for such feeding experiments, causing no significant alterations in food intake when administered alone, even with solutions at concentrations as high as $75 \%[29,31]$. Upon completion of antagonist/inhibitor injections an additional minute elapsed before removing injectors to minimize backflow of injected material. Five minutes later (15 minutes for PP1 studies) rats received a second bilateral injection of either saline or PACAP (50 pmol/0.25 $\mu \mathrm{l} /$ side; PACAP38; California Peptide Research; Napa, CA) and upon completion animals were returned to their home cage for subsequent feeding measurements. The optimal injection volume of $0.25 \mu \mathrm{l}$ to contain microinjections within VMN was determined previously [21]. Feeding measurements were collected for the next 24 hours, with the greatest emphasis placed on the first 3-5 hours after microinjections were delivered.

\section{Western blot analysis of GluN2B tyrosine phosphorylation}

Thirty minutes following saline or PACAP ( $50 \mathrm{pmol} / 0.25 \mu \mathrm{l} / \mathrm{side}$ ) injections into the VMN, bilateral dissections of the ventromedial hypothalamus ( $\mathrm{VMH}$; including the VMN and surrounding areas) were collected. VMH tissue was homogenized by hand (10 strokes) in icecold homogenization buffer ( $320 \mathrm{mM}$ sucrose, $10 \mathrm{mM}$ Tris- $\mathrm{HCl}, \mathrm{pH}$ 7.4,

Physiology \& Behavior, Vol. 133, No. 22 (June 2014): pg. 230-235. DOI. This article is @ Elsevier and permission has been granted for this version to appear in e-Publications@Marquette. Elsevier does not grant permission for this article to be further copied/distributed or hosted elsewhere without the express permission from Elsevier. 
10mM EDTA, 10mM EGTA) containing Halt protease and phosphatase inhibitor cocktail (Pierce; Rockfork, IL), followed by 3-4 seconds of sonication. Homogenates were centrifuged at $1000 \mathrm{X}$ g for 2 minutes at $4^{\circ} \mathrm{C}$ to remove nuclei and large debris. The resulting supernatant was further centrifuged at $10,000 \times \mathrm{g}$ for 30 minutes at $4^{\circ} \mathrm{C}$ to obtain a crude membranal pellet that was resuspended in solubilization buffer ( $1 \%$ Triton $\mathrm{x}-100,150 \mathrm{mM} \mathrm{NaCl}$, 10nM Tris-HCl pH 7.4, 1 mM EDTA, 1 mM EGT, protease \& phosphatase inhibitor cocktail). Protein quantification of samples was determined using a bicinchoninic (BCA) assay (Pierce). Membrane protein $(20 \mu \mathrm{g})$ was run on an $8 \%$ gel by SDS-PAGE and transferred to a polyvinylidine fluoride (PVDF) membrane. Membranes were blocked with $5 \%$ bovine serum albumin (BSA) in tris-buffered saline containing $0.1 \%$ Tween-20 (TBS-T). Blots were then probed with rabbit anti-pY1336 GluN2B antibody (Rockland Immunochemicals; Gilbertsville, PA) overnight at $4^{\circ} \mathrm{C}$, followed by washes with TBS-T and incubation with an HRP-conjugated mouse anti-rabbit secondary antibody (Jackson Immunoresearch; West Grove, PA) at room temperature for 2 hours. Band intensities for pY1336 were developed using SuperSignal West Femto chemiluminescent substrate (Pierce) and visualized using the Kodak Image Station 4000MM. After visualization of pY1336 signal, blots were stripped and reprobed in an identical fashion for total GluN2B expression using mouse anti-GluN2B (Rockland Immunochemicals) and HRP-conjugated goat anti-mouse (Jackson Immunoresearch) antibodies. Band densities were measured using Kodak Molecular Imaging Software v4.0.

\section{Statistics}

Data are presented as means \pm standard errors of the mean, and were analyzed statistically by analysis of variance (with repeated measures when appropriate). Fischer LSD analysis was used for all post-hoc group comparisons. Statistical analyses were performed using Sigma Plot 11 software (Systat Software Inc.; San Jose, CA). P $<0.05$ were considered statistically significant.

\section{Results}

Our previous efforts to characterize the effects of PACAP signaling in the hypothalamus have demonstrated a PAC1R-dependent

Physiology \& Behavior, Vol. 133, No. 22 (June 2014): pg. 230-235. DOI. This article is (C Elsevier and permission has been granted for this version to appear in e-Publications@Marquette. Elsevier does not grant permission for this article to be further copied/distributed or hosted elsewhere without the express permission from Elsevier. 
decrease in food intake following site-specific injections into the VMN $[21,22]$. Considering previous associations between PACAP and NMDA receptor signaling $[24,25,28,32]$, as well as the potential of NMDA receptor activity to regulate feeding behavior $[11,12,29,33]$, we proceeded to test whether glutamate signaling via the NMDA receptor was necessary for PACAP-mediated reductions in food intake. Initially, the NMDA receptor antagonist AP5 was administered bilaterally into the VMN at multiple doses ranging from $10 \mathrm{pmol}$ to $1 \mathrm{nmol}$ to investigate its contribution to normal nocturnal feeding behavior. Surprisingly, none of the three doses tested significantly altered feeding behavior (Fig. 7.4A). To determine whether NMDA receptor function is necessary for PACAP-mediated decreased food intake, animals received AP5 (10 pmol/side) injections into the VMN prior to PACAP (50 pmol/side). Although AP5 treatment alone again had no effect on feeding, it did successfully block the effects of PACAP injections into the VMN on food intake (Fig. 7.4B; $\mathrm{P}<0.05$ ).

With the evidence that NMDA receptor function appears to be necessary for decreased food intake induced by PACAP, we examined whether similar mechanisms of NMDA receptor potentiation by PACAP existed within the hypothalamus as has been reported in the hippocampus $[25,28]$. PACAP treatment of hippocampal slices was found to produce increased phosphorylation of tyrosines 1252, 1336, and 1472 specifically on the GluN2B subunit of NMDA receptors [28], therefore to test for tyrosine phosphorylation under our conditions we performed microinjections of saline or PACAP in a similar manner prior to feeding experiments but collected VMH tissue 30 minutes postinjection for GluN2B tyrosine phosphorylation analysis. In western blotting experiments we examined phosphorylation levels of tyrosine 1336 ( $p$ 1336) on the GluN2B subunit of the NMDA receptor and normalized band intensities to total GluN2B expression. Indeed, semiquantitative analysis demonstrated that VMN PACAP treatment increased pY1336 expression by approximately 25\% (Fig. 7.5A \& B; P $<0.05)$.

Tyrosine phosphorylation of the NMDA receptor mediated by PACAP signaling has been associated with increased Src family kinase activity $[25,28]$, which has also been implicated in the regulation of feeding behavior by the lateral hypothalamus [29]. Supported by the studies conducted in the hippocampus [28] as well as the data

Physiology \& Behavior, Vol. 133, No. 22 (June 2014): pg. 230-235. DOI. This article is (C) Elsevier and permission has been granted for this version to appear in e-Publications@Marquette. Elsevier does not grant permission for this article to be further copied/distributed or hosted elsewhere without the express permission from Elsevier. 
presented here, the phosphorylation appears to be specific to the GluN2B subunit of the NMDA receptor. Taken together it is probable that PACAP-PAC1R signaling results in tyrosine phosphorylation of the GluN2B subunit of the NMDA receptor in the VMN through activation of an Src kinase. To confirm this possibility the Src kinase inhibitor PP1 (1 - $1000 \mathrm{pmol} / 0.25 \mathrm{\mu l} / \mathrm{side}$ ) was injected into the VMN followed by measurements of food intake. No concentration of PP1 used in these studies significantly altered food intake when injected into the VMN alone (Fig. 7.6A). However, pretreatment with PP1 (10 pmol/side) in the VMN prior to PACAP injections did significantly attenuate the hypophagic effects of PACAP (Fig. 7.6B; P < 0.05).

\section{Discussion}

By inhibiting NMDA receptor signaling we were able to examine the contribution of its activity to PACAP-mediated decreases in food intake in the VMN. Pretreatment with the NMDA receptor antagonist AP5 successfully attenuated the hypophagic response to PACAP administration into the VMN. These data build upon previous findings indicating that PACAP-PAC1R signaling may potentiate postsynaptic NMDA receptor activity (Figure 4) [24, 25, 32], perhaps through phosphorylation of the GluN2B subunit [28]. Upon examination of GluN2B phosphorylation following PACAP injections into the VMN in vivo, we detected an increase in phosphorylation at tyrosine 1336, a previously identified site of PACAP-induced tyrosine phosphorylation on the GluN2B subunit of the NMDA receptor [28]. Not only has the Src family of non-receptor tyrosine kinases been previously described to facilitate NMDA receptor phosphorylation mediated by PACAP $[25,28]$, but hypothalamic Src activity has been demonstrated to play a role in the regulation of feeding behavior [29]. These findings led us to test whether Src was a downstream mediator of PACAP-induced hypophagia in the VMN. Inhibition of Src family tyrosine kinases with PP1 effectively blocked the effects of intra-VMN PACAP on feeding behavior, thus supporting a mechanism for PACAP-mediated potentiation of NMDA receptors via an Src-dependent pathway.

Similar to our current data combining NMDA receptor antagonists with PACAP injections into the VMN, inhibition of NMDA receptors also blocks hyperphagia induced by orexin and neuropeptide $Y$ in the lateral hypothalamus as well as refeeding following a fast [11,

Physiology \& Behavior, Vol. 133, No. 22 (June 2014): pg. 230-235. DOI. This article is @ Elsevier and permission has been granted for this version to appear in e-Publications@Marquette. Elsevier does not grant permission for this article to be further copied/distributed or hosted elsewhere without the express permission from Elsevier. 
12]. In contrast, AMPA/kainate and NMDA glutamate receptor agonists produce robust feeding in sated rats when administered into the lateral hypothalamus $[7,33,34]$. Although treatment with AP5 in the VMN did not produce increased feeding behavior as one might expect, AP5 was administered at a time when feeding behavior was naturally at its peak, possibly reducing our ability to detect AP5-induced alterations in feeding behavior. However, our current findings indicate that VMN PACAP injections produce NMDAR-dependent hypophagia and GluN2B tyrosine phosphorylation, and that NMDA receptors in the VMN significantly regulate feeding behavior. In the lateral hypothalamus, antagonism of GluN2B containing NMDA receptors with ifenprodil attenuates the feeding response to both fasting and microinjection of NMDA into the lateral hypothalamus, although ifenprodil concentrations used in these studies may have also antagonized GluN2A containing NMDA receptors [36]. The phosphorylation state of the GluN2B subunit may be critical for augmenting NMDA receptor activity induced by PACAP signaling, and appears to be regulated by the Src family of tyrosine kinases $[25,28]$, a family of kinases that is critical to the function and signaling of NMDA receptors also reported to reduce GluN3A trafficking to the synaptic membrane [37-39]. Importantly, inhibition of Src family tyrosine kinases by PP1 has previously been reported to block NMDAR-dependent feeding behavior in the lateral hypothalamus [29], similar to our data regarding PACAP signaling in the VMN.

Although our investigations of PACAP-mediated feeding behavior in the VMN cannot directly demonstrate potentiation of postsynaptic NMDA receptors by PACAP signaling, extensive biochemical and electrophysiological analysis of glutamate signaling in the hippocampus has demonstrated this modulatory pathway. PACAP application yields enhancement of field excitatory postsynaptic potentials, brain derived neurotrophic factor mRNA expression, and tyrosine phosphorylation of the GluN2B subunit of the NMDA receptor by Fyn tyrosine kinase, which is a member of the Src family of tyrosine kinases [28]. Further coupling PACAP to glutamate signaling, PACAP augments NMDA currents following Schaffer collateral stimulation through a PAC1Rdependent pathway that activates Src tyrosine kinase [25]. While two different mechanisms of NMDA receptor potentiation by PACAP have been identified, both occur as a result of tyrosine phosphorylation of

Physiology \& Behavior, Vol. 133, No. 22 (June 2014): pg. 230-235. DOI. This article is @ Elsevier and permission has been granted for this version to appear in e-Publications@Marquette. Elsevier does not grant permission for this article to be further copied/distributed or hosted elsewhere without the express permission from Elsevier. 
NMDA receptors by a member of the Src family of tyrosine kinases (Fyn and Src).

PACAP signaling may also modulate other aspects of glutamate signaling including the AMPA receptor, as PAC1R-dependent potentiation of AMPA receptors at low PACAP concentrations and VPAC2R-mediated depression of AMPA receptors at high concentrations of PACAP have been reported in the hippocampus [40]. Furthermore, excitatory transmission from the basolateral amygdala to the central amygdala is augmented through PACAP-VPAC1R increases in AMPA receptor activity [41]. However, without further behavioral pharmacology examining glutamate receptor-mediated properties of PACAP-induced hypophagia in combination with the appropriate electrophysiology, the role of other modes of glutamatergic neurotransmission cannot be ascertained at this time. Nevertheless, our experiments using AP5 and PP1 attenuated the effects of PACAP on feeding suggesting a similar mechanism of NMDA receptor modulation by PACAP likely exists in the hypothalamus as it does in the hippocampus.

Glutamate is also substantially regulated by astrocytes, which are major targets of PACAP signaling [42-44], yielding another potentially important mechanism for glutamate modulation by PACAP. Astrocytes impact glutamate neurotransmission most notably through removal of synaptic glutamate by sodium-dependent excitatory amino acid transporters (EAATs) [45-47] and glutamate release from astrocytes themselves [48-52]. Given that a single astrocyte can interact with numerous synapses [53,54], their influence over glutamate signaling and overall network activity is immense. PACAP is already known to increase expression of both GLAST and GLT-1 (EAAT1 and EAAT2 respectively) in primary cortical astrocyte cultures [55], therefore, investigation into how astrocytic glutamate regulation is further influenced by PACAP may reveal new insights into signaling mechanisms that are important to glutamate homeostasis and may influence behavior. Despite the extensive study of how astrocytic control of glutamate affects hypothalamic function [6, 56-58] and knowledge that PACAP potently regulates feeding behavior $[22,59-$ $61]$, whether or not modulation of astrocytic glutamate signaling by PACAP influences food intake has yet to be investigated.

Physiology \& Behavior, Vol. 133, No. 22 (June 2014): pg. 230-235. DOI. This article is (C) Elsevier and permission has been granted for this version to appear in e-Publications@Marquette. Elsevier does not grant permission for this article to be further copied/distributed or hosted elsewhere without the express permission from Elsevier. 
The studies described here further our understanding of PACAP signaling in the hypothalamus with regard to feeding behavior. Previous reports have suggested that PACAP augments NMDA receptor activity $[24,25,28,32]$. In the current study, inhibition of NMDA receptor signaling is sufficient to mitigate the hypophagic response to PACAP administration in the VMN suggesting a similar relationship exists between PACAP and NMDA receptor signaling in the hypothalamus. Furthermore, this NMDA receptor modulation by PACAP appears to be mediated through Src family kinase signaling, which is critical to both NMDA receptor function as well as the regulation of feeding behavior [29, 38, 39]. Given the identified pleiotropic actions of PACAP, further investigation is warranted to address other mechanisms of glutamate modulation by this neuropeptide and how such mechanisms are involved in the regulation of feeding behavior.

\section{Acknowledgments}

This research was supported by NIH grant DK074734

\section{References}

[1] Liu, T., Kong, D., Shah, B. P., Ye, C., Koda, S., Saunders, A., et al. Fasting activation of AgRP neurons requires NMDA receptors and involves spinogenesis and increased excitatory tone. Neuron. 2012,73:511-22.

[2] Xu, Y., Kim, E. R., Zhao, R., Myers, M. G., Jr., Munzberg, H., Tong, Q. Glutamate release mediates leptin action on energy expenditure. Molecular metabolism. 2013,2:109-15.

[3] Xu, Y., Wu, Z., Sun, H., Zhu, Y., Kim, E. R., Lowell, B. B., et al. Glutamate mediates the function of melanocortin receptor 4 on $\operatorname{Sim} 1$ neurons in body weight regulation. Cell Metab. 2013,18:860-70.

[4] Tong, Q., Ye, C., McCrimmon, R. J., Dhillon, H., Choi, B., Kramer, M. D., et al. Synaptic glutamate release by ventromedial hypothalamic neurons is part of the neurocircuitry that prevents hypoglycemia. Cell Metab. 2007,5:383-93.

[5] Sternson, S. M., Shepherd, G. M., Friedman, J. M. Topographic mapping of VMH --> arcuate nucleus microcircuits and their reorganization by fasting. Nat Neurosci. 2005,8:1356-63.

[6] Fuente-Martin, E., Garcia-Caceres, C., Granado, M., de Ceballos, M. L., SanchezGarrido, M. A., Sarman, B., et al. Leptin regulates glutamate and glucose transporters in hypothalamic astrocytes. J Clin Invest. 2012,122:3900-13.

[7] Stanley, B. G., Ha, L. H., Spears, L. C., Dee, M. G., 2nd. Lateral hypothalamic injections of glutamate, kainic acid, D,L-alpha-amino-3-hydroxy-5-methyl-isoxazole

Physiology \& Behavior, Vol. 133, No. 22 (June 2014): pg. 230-235. DOI. This article is (C) Elsevier and permission has been granted for this version to appear in e-Publications@Marquette. Elsevier does not grant permission for this article to be further copied/distributed or hosted elsewhere without the express permission from Elsevier. 
NOT THE PUBLISHED VERSION; this is the author's final, peer-reviewed manuscript. The published version may be accessed by following the link in the citation at the bottom of the page.

propionic acid or $\mathrm{N}$-methyl-D-aspartic acid rapidly elicit intense transient eating in rats. Brain Res. 1993,613:88-95.

[8] Takaki, A., Aou, S., Oomura, Y., Okada, E., Hori, T. Feeding suppression elicited by electrical and chemical stimulations of monkey hypothalamus. Am J Physiol. 1992,262:R586-94.

[9] Guyenet, S. J., Matsen, M. E., Morton, G. J., Kaiyala, K. J., Schwartz, M. W. Rapid glutamate release in the mediobasal hypothalamus accompanies feeding and is exaggerated by an obesogenic food. Molecular metabolism. 2013,2:116-22.

[10] van den Pol, A. N. Neuropeptide transmission in brain circuits. Neuron. 2012,76:98115.

[11] Lee, S. W., Stanley, B. G. NMDA receptors mediate feeding elicited by neuropeptide $Y$ in the lateral and perifornical hypothalamus. Brain Res. 2005,1063:1-8.

[12] Doane, D. F., Lawson, M. A., Meade, J. R., Kotz, C. M., Beverly, J. L. Orexin-induced feeding requires NMDA receptor activation in the perifornical region of the lateral hypothalamus. Am J Physiol Regul Integr Comp Physiol. 2007,293:R10226.

[13] Borgland, S. L., Storm, E., Bonci, A. Orexin B/hypocretin 2 increases glutamatergic transmission to ventral tegmental area neurons. Eur J Neurosci. 2008,28:154556.

[14] Meeker, R. B., Greenwood, R. S., Hayward, J. N. Glutamate receptors in the rat hypothalamus and pituitary. Endocrinology. 1994,134:621-9.

[15] Ziegler, D. R., Cullinan, W. E., Herman, J. P. Distribution of vesicular glutamate transporter mRNA in rat hypothalamus. J Comp Neurol. 2002,448:217-29.

[16] Fu, L. Y., van den Pol, A. N. Agouti-related peptide and MC3/4 receptor agonists both inhibit excitatory hypothalamic ventromedial nucleus neurons. J Neurosci. 2008,28:5433-49.

[17] Amir, S. Intra-ventromedial hypothalamic injection of glutamate stimulates brown adipose tissue thermogenesis in the rat. Brain Res. 1990,511:341-4.

[18] Yoshimatsu, H., Egawa, M., Bray, G. A. Sympathetic nerve activity after discrete hypothalamic injections of L-glutamate. Brain Res. 1993,601:121-8.

[19] Ruffin, M., Nicolaidis, S. Electrical stimulation of the ventromedial hypothalamus enhances both fat utilization and metabolic rate that precede and parallel the inhibition of feeding behavior. Brain Res. 1999,846:23-9.

[20] Beltt, B. M., Keesey, R. E. Hypothalamic map of stimulation current thresholds for inhibition of feeding in rats. Am J Physiol. 1975,229:1124-33.

[21] Resch, J. M., Boisvert, J. P., Hourigan, A. E., Mueller, C. R., Yi, S. S., Choi, S. Stimulation of the hypothalamic ventromedial nuclei by pituitary adenylate cyclase-activating polypeptide induces hypophagia and thermogenesis. Am J Physiol Regul Integr Comp Physiol. 2011,301:R1625-34.

[22] Resch, J. M., Maunze, B., Gerhardt, A. K., Magnuson, S. K., Phillips, K. A., Choi, S. Intrahypothalamic pituitary adenylate cyclase-activating polypeptide regulates

Physiology \& Behavior, Vol. 133, No. 22 (June 2014): pg. 230-235. DOI. This article is @ Elsevier and permission has been granted for this version to appear in e-Publications@Marquette. Elsevier does not grant permission for this article to be further copied/distributed or hosted elsewhere without the express permission from Elsevier. 
NOT THE PUBLISHED VERSION; this is the author's final, peer-reviewed manuscript. The published version may be accessed by following the link in the citation at the bottom of the page.

energy balance via site-specific actions on feeding and metabolism. Am J Physiol Endocrinol Metab. 2013,305:E1452-63.

[23] Hannibal, J., Moller, M., Ottersen, O. P., Fahrenkrug, J. PACAP and glutamate are costored in the retinohypothalamic tract. J Comp Neurol. 2000,418:147-55.

[24] Harrington, M. E., Hoque, S., Hall, A., Golombek, D., Biello, S. Pituitary adenylate cyclase activating peptide phase shifts circadian rhythms in a manner similar to light. J Neurosci. 1999,19:6637-42.

[25] Macdonald, D. S., Weerapura, M., Beazely, M. A., Martin, L., Czerwinski, W., Roder, J. C., et al. Modulation of NMDA receptors by pituitary adenylate cyclase activating peptide in $\mathrm{CA} 1$ neurons requires $\mathrm{G}$ alpha $\mathrm{q}$, protein kinase $\mathrm{C}$, and activation of Src. J Neurosci. 2005,25:11374-84.

[26] Fahrenkrug, J., Hannibal, J. Neurotransmitters co-existing with VIP or PACAP. Peptides. 2004,25:393-401.

[27] Engelund, A., Fahrenkrug, J., Harrison, A., Hannibal, J. Vesicular glutamate transporter 2 (VGLUT2) is co-stored with PACAP in projections from the rat melanopsin-containing retinal ganglion cells. Cell and tissue research. 2010,340:243-55.

[28] Yaka, R., He, D. Y., Phamluong, K., Ron, D. Pituitary adenylate cyclase-activating polypeptide (PACAP(1-38)) enhances $\mathrm{N}$-methyl-D-aspartate receptor function and brain-derived neurotrophic factor expression via RACK1. J Biol Chem. 2003,278:9630-8.

[29] Khan, A. M., Cheung, H. H., Gillard, E. R., Palarca, J. A., Welsbie, D. S., Gurd, J. W., et al. Lateral hypothalamic signaling mechanisms underlying feeding stimulation: differential contributions of Src family tyrosine kinases to feeding triggered either by NMDA injection or by food deprivation. J Neurosci. 2004,24:10603-15.

[30] Paxinos, G., Watson, C. The Rat Brain in Stereotaxic Coordinates. Sixth Edition ed. San Diego, CA: Academic Press; 2007.

[31] Blevins, J. E., Stanley, B. G., Reidelberger, R. D. DMSO as a vehicle for central injections: tests with feeding elicited by norepinephrine injected into the paraventricular nucleus. Pharmacol Biochem Behav. 2002,71:277-82.

[32] Wu, S. Y., Dun, N. J. Potentiation of NMDA currents by pituitary adenylate cyclase activating polypeptide in neonatal rat sympathetic preganglionic neurons. Journal of neurophysiology. 1997,78:1175-9.

[33] Stanley, B. G., Willett, V. L., 3rd, Donias, H. W., Dee, M. G., 2nd, Duva, M. A. Lateral hypothalamic NMDA receptors and glutamate as physiological mediators of eating and weight control. Am J Physiol. 1996,270:R443-9.

[34] Stanley, B. G., Willett, V. L., 3rd, Donias, H. W., Ha, L. H., Spears, L. C. The lateral hypothalamus: a primary site mediating excitatory amino acid-elicited eating. Brain Res. 1993,630:41-9.

[35] Khan, A. M., Stanley, B. G., Bozzetti, L., Chin, C., Stivers, C., Curras-Collazo, M. C. Nmethyl-D-aspartate receptor subunit NR2B is widely expressed throughout the

Physiology \& Behavior, Vol. 133, No. 22 (June 2014): pg. 230-235. DOI. This article is @ Elsevier and permission has been granted for this version to appear in e-Publications@Marquette. Elsevier does not grant permission for this article to be further copied/distributed or hosted elsewhere without the express permission from Elsevier. 
NOT THE PUBLISHED VERSION; this is the author's final, peer-reviewed manuscript. The published version may be accessed by following the link in the citation at the bottom of the page.

rat diencephalon: an immunohistochemical study. J Comp Neurol. 2000,428:428-49.

[36] Khan, A. M., Curras, M. C., Dao, J., Jamal, F. A., Turkowski, C. A., Goel, R. K., et al. Lateral hypothalamic NMDA receptor subunits NR2A and/or NR2B mediate eating: immunochemical/behavioral evidence. Am J Physiol. 1999,276:R880-91.

[37] Chowdhury, D., Marco, S., Brooks, I. M., Zandueta, A., Rao, Y., Haucke, V., et al. Tyrosine phosphorylation regulates the endocytosis and surface expression of GluN3A-containing NMDA receptors. J Neurosci. 2013,33:4151-64.

[38] Groveman, B. R., Feng, S., Fang, X. Q., Pflueger, M., Lin, S. X., Bienkiewicz, E. A., et al. The regulation of $\mathrm{N}$-methyl-D-aspartate receptors by Src kinase. The FEBS journal. 2012,279:20-8.

[39] Trepanier, C. H., Jackson, M. F., MacDonald, J. F. Regulation of NMDA receptors by the tyrosine kinase Fyn. The FEBS journal. 2012,279:12-9.

[40] Costa, L., Santangelo, F., Li Volsi, G., Ciranna, L. Modulation of AMPA receptormediated ion current by pituitary adenylate cyclase-activating polypeptide (PACAP) in CA1 pyramidal neurons from rat hippocampus. Hippocampus. 2009,19:99-109.

[41] Cho, J. H., Zushida, K., Shumyatsky, G. P., Carlezon, W. A., Jr., Meloni, E. G., Bolshakov, V. Y. Pituitary adenylate cyclase-activating polypeptide induces postsynaptically expressed potentiation in the intra-amygdala circuit. J Neurosci. 2012,32:14165-77.

[42] Tatsuno, I., Morio, H., Tanaka, T., Hirai, A., Tamura, Y., Saito, Y., et al. Astrocytes are one of the main target cells for pituitary adenylate cyclase-activating polypeptide in the central nervous system. Astrocytes are very heterogeneous regarding both basal movement of intracellular free calcium ([Ca2+]i) and the [Ca2+]i response to PACAP at a single cell level. Ann N Y Acad Sci. 1996,805:6139.

[43] Tatsuno, I., Morio, H., Tanaka, T., Uchida, D., Hirai, A., Tamura, Y., et al. Pituitary adenylate cyclase-activating polypeptide (PACAP) is a regulator of astrocytes: PACAP stimulates proliferation and production of interleukin 6 (IL-6), but not nerve growth factor (NGF), in cultured rat astrocyte. Ann N Y Acad Sci. 1996,805:482-8.

[44] Masmoudi-Kouki, O., Gandolfo, P., Castel, H., Leprince, J., Fournier, A., Dejda, A., et al. Role of PACAP and VIP in astroglial functions. Peptides. 2007,28:1753-60.

[45] Asztely, F., Erdemli, G., Kullmann, D. M. Extrasynaptic glutamate spillover in the hippocampus: dependence on temperature and the role of active glutamate uptake. Neuron. 1997,18:281-93.

[46] Diamond, J. S., Jahr, C. E. Synaptically released glutamate does not overwhelm transporters on hippocampal astrocytes during high-frequency stimulation. Journal of neurophysiology. 2000,83:2835-43.

Physiology \& Behavior, Vol. 133, No. 22 (June 2014): pg. 230-235. DOI. This article is @ Elsevier and permission has been granted for this version to appear in e-Publications@Marquette. Elsevier does not grant permission for this article to be further copied/distributed or hosted elsewhere without the express permission from Elsevier 
NOT THE PUBLISHED VERSION; this is the author's final, peer-reviewed manuscript. The published version may be accessed by following the link in the citation at the bottom of the page.

[47] Zheng, K., Scimemi, A., Rusakov, D. A. Receptor actions of synaptically released glutamate: the role of transporters on the scale from nanometers to microns. Biophysical journal. 2008,95:4584-96.

[48] Baker, D. A., Xi, Z. X., Shen, H., Swanson, C. J., Kalivas, P. W. The origin and neuronal function of in vivo nonsynaptic glutamate. J Neurosci. 2002,22:9134-41.

[49] Moran, M. M., McFarland, K., Melendez, R. I., Kalivas, P. W., Seamans, J. K. Cystine/glutamate exchange regulates metabotropic glutamate receptor presynaptic inhibition of excitatory transmission and vulnerability to cocaine seeking. J Neurosci. 2005,25:6389-93.

[50] Kupchik, Y. M., Moussawi, K., Tang, X. C., Wang, X., Kalivas, B. C., Kolokithas, R., et al. The effect of $\mathrm{N}$-acetylcysteine in the nucleus accumbens on neurotransmission and relapse to cocaine. Biological psychiatry. 2012,71:97886.

[51] Parpura, V., Haydon, P. G. Physiological astrocytic calcium levels stimulate glutamate release to modulate adjacent neurons. Proc Natl Acad Sci U S A. 2000,97:8629-34.

[52] Ye, Z. C., Wyeth, M. S., Baltan-Tekkok, S., Ransom, B. R. Functional hemichannels in astrocytes: a novel mechanism of glutamate release. J Neurosci. 2003,23:358896.

[53] Bushong, E. A., Martone, M. E., Jones, Y. Z., Ellisman, M. H. Protoplasmic astrocytes in CA1 stratum radiatum occupy separate anatomical domains. J Neurosci. 2002,22:183-92.

[54] Ogata, K., Kosaka, T. Structural and quantitative analysis of astrocytes in the mouse hippocampus. Neuroscience. 2002,113:221-33.

[55] Figiel, M., Engele, J. Pituitary adenylate cyclase-activating polypeptide (PACAP), a neuron-derived peptide regulating glial glutamate transport and metabolism. J Neurosci. 2000,20:3596-605.

[56] Oliet, S. H., Piet, R., Poulain, D. A. Control of glutamate clearance and synaptic efficacy by glial coverage of neurons. Science. 2001,292:923-6.

[57] Gordon, G. R., Iremonger, K. J., Kantevari, S., Ellis-Davies, G. C., MacVicar, B. A., Bains, J. S. Astrocyte-mediated distributed plasticity at hypothalamic glutamate synapses. Neuron. 2009,64:391-403.

[58] Potapenko, E. S., Biancardi, V. C., Zhou, Y., Stern, J. E. Altered astrocyte glutamate transporter regulation of hypothalamic neurosecretory neurons in heart failure rats. Am J Physiol Regul Integr Comp Physiol. 2012,303:R291-300.

[59] Morley, J. E., Horowitz, M., Morley, P. M., Flood, J. F. Pituitary adenylate cyclase activating polypeptide (PACAP) reduces food intake in mice. Peptides. 1992,13:1133-5.

[60] Hawke, Z., Ivanov, T. R., Bechtold, D. A., Dhillon, H., Lowell, B. B., Luckman, S. M. PACAP neurons in the hypothalamic ventromedial nucleus are targets of central leptin signaling. J Neurosci. 2009,29:14828-35.

Physiology \& Behavior, Vol. 133, No. 22 (June 2014): pg. 230-235. DOI. This article is @ Elsevier and permission has been granted for this version to appear in e-Publications@Marquette. Elsevier does not grant permission for this article to be further copied/distributed or hosted elsewhere without the express permission from Elsevier. 
[61] Mounien, L., Do Rego, J. C., Bizet, P., Boutelet, I., Gourcerol, G., Fournier, A., et al. Pituitary adenylate cyclase-activating polypeptide inhibits food intake in mice through activation of the hypothalamic melanocortin system.

Neuropsychopharmacology. 2009,34:424-35.

\section{Figure Legends}

Figure 1. NMDA receptor antagonism attenuates the hypophagic effects of PACAP administration into the VMN. (A) Feeding responses to a dose-response of bilateral AP5 microinjections into the VMN. (B) Bilateral injection of 10 pmol AP5 into the VMN blocks the inhibitory effect of PACAP on feeding behavior. Data are expressed as mean \pm SEM. $*=\mathrm{P}<0.05$ compared to control group.

Figure 2. PACAP administration into the $V M N$ results in increased tyrosine phosphorylation of the GluN2B subunit of the NMDA receptor. (A) Representative VMH protein samples from saline or PACAP (50 $\mathrm{pmol} / \mathrm{side}$ ) microinjections into the VMN probed for phosphorylation of tyrosine 1336 of the GluN2b subunit (pY1336) and total GluN2B protein expression. (B) Semi-quantitative analysis of band densities for pY1336 normalized to total GluN2b expression expressed as a percent of saline treatment. Data are expressed as mean \pm SEM. $*=P<0.05$

Figure 3. Inhibition of Src kinase activity with PP1 attenuates PACAPinduced decreases in food intake in the VMN. (A) Feeding response to PP1 injections into the VMN. (B) Pretreatment of the VMN with PP1 prior to PACAP injections prevents PACAP-mediated hypophagia. Data are expressed as mean \pm SEM. $*=\mathrm{P}<0.05$ compared to control group.

Figure 4. Modulation of NMDA receptor signaling by PACAP. (A) Conventional glutamatergic synapse showing no modulation of glutamate neurotransmission leading to lesser excitatory postsynaptic potential (EPSP). (B) Proposed potentiation of EPSP following modulation of glutamate receptors by PACAP released from glutamate and PACAP co-expressing neurons or PACAPergic neurons.

Physiology \& Behavior, Vol. 133, No. 22 (June 2014): pg. 230-235. DOI. This article is (C) Elsevier and permission has been granted for this version to appear in e-Publications@Marquette. Elsevier does not grant permission for this article to be further copied/distributed or hosted elsewhere without the express permission from Elsevier. 